\title{
Новое практико-ориентированное учебное пособие для экологов
}

\author{
(Каверина Н. В., Прожсоина Т.И., Иванова Е. Ю., Клевцова М. А., Куролап С.А., \\ Клепиков О. В., Муравьев А. Г., Никольская А. Н., Синегубова В. В. Методы \\ экологических исследований: учебное пособие для вузов [гриф ФУМО «Науки о \\ Земле»]. Воронеж, Издательство «Научная книга», 2019. 355 с.)
}

\author{
А. Г. Корнилов $\bowtie$ \\ Белгородский государственный национальный исследовательский университет, \\ Российская Федераиия \\ (308015, г. Белгород, ул. Победы, 85)
}

\begin{abstract}
Для цитирования: Корнилов А. Г. Новое практико-ориентированное учебное пособие для экологов // Вестник Воронежского государственного университета. Серия География. Геоэкология, 2020, № 3, c. 98-100. DOI: https://doi.org/10.17308/geo.2020.3/3030
\end{abstract}

Вышло в свет новое учебное пособие для образовательных учреждений высшего образования России - «Методы экологических исследований» / Н. В. Каверина и др., 2019 - актуальность и значимость которого отмечена грифом Федерального учебно-методического объединения «Науки о Земле» для студентов, обучающихся по направлению «Экология и природопользование».

Подготовленное учебное пособие отражает опыт реализации практико-ориентированного подхода в современном экологическом образовании университетского уровня. Подобный подход разработан и уже многие годы успешно применяется в системе эколого-географического образования на факультете географии, геоэкологии и туризма Воронежского государственного университета. Он отражает принцип «сквозной» эколого-аналитической подготовки в рамках различных базовых и вариативных дисциплин государственных образовательных стандартов направления «Экология и природопользование» (уровни бакалавриат и магистратура). Будущим специалистам целесообразно осваивать лабораторно-инструментальные методы исследовании в ходе аудиторного преподавания, а также при проведении полевых учебных и производственных практик.

Очень важно, что опубликованное издание содержит практические методики лабораторных эко- лого-аналитических исследований, необходимые для подготовки эколога-практика в системе высшего образования. Авторы настоящего учебного пособия продемонстрировали наиболее типичные лабораторные работы, которые апробированы в учебном процессе на базе аттестованной учебной эколого-аналитической лаборатории Воронежского университета. В учебном пособии описаны подходы к анализу воздушной, водной и почвенной сред с помощью оригинальных экогеохимических методов, методов биоиндикации и биотестирования объектов окружающей среды. Отдельные разделы посвящены описанию функциональных возможностей лабораторного оборудования и приборной базы исследований, в том числе с помощью стационарных лабораторных и экспресс-методов экологической диагностики среды обитания. Описаны основные принципы и алгоритмы математико-статистической обработки получаемых данных, а также принципы их содержательной интерпретации. Отдельный раздел посвящен изложению современных методов оценки риска для здоровья населения, связанного с химическим загрязнением среды обитания, и составлению типового Проекта оценки риска для здоровья населения, применяемого в практической работе эколога.

Ряд лабораторных работ в области эколого-химических исследований состояния окружающей

() Корнилов А.Г., 2020

\ Корнилов Андрей Геннадьевич, e-mail: kornilov@bsu.edu.ru

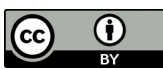

98

Контент доступен под лицензией Creative Commons Attribution 4.0 License. 
среды подготовлен совместно в рамках творческого сотрудничества между факультетом географии, геоэкологии и туризма ВГУ и его многолетним партнером - научно-производственным объединением Закрытым акционерным обществом «Крисмас+» (г. Санкт-Петербург) - ведущим предприятием отечественной индустрии по производству и оснащению учебных заведений и профессиональных служб современным лабораторным оборудованием и приборами для изучения качества окружающей среды химическими экспресс-методами.

В структурном отношении учебное пособие включает четыре основных раздела: 1) современные методы эколого-аналитических исследований; 2) эколого-химические (экогеохимические) методы анализа и контроля состояния воздушной, водной и почвенной сред; 3) методы биотестирования и биоиндикации; 4) статистические методы оценки экологического риска для здоровья населения.
Всего приведено описание 86 лабораторных работ, которые будут полезны при проведении практических и лабораторных занятий по дисциплинам экологической ориентации, а также в полевых условиях при контроле экологических характеристик объектов окружающей среды.

Представленные лабораторные работы в большинстве случаев сопровождаются необходимыми теоретическими разделами. Изложение материала методически грамотное и информативное, а все работы носят оригинальный авторский характер.

Изданное учебное пособие «Методы экологических исследований» будет замечено научно-педагогическим сообществом России и станет востребованным при подготовке специалистов в системе университетского экологического образования.

Конфликт интересов: Автор декларирует отсутствие явных и потенциальных конфликтов интересов, связанных с публикацией настоящей статьи.

Поступила в редакцию 09.06.2020 Принята к публикаичи 26.07.2020

UDC 504:550.4(07)

ISSN 1609-0683

DOI: https://doi.org/10.17308/geo.2020.3/3030

\title{
New Practice-Oriented Study Guide for Environmentalists
}

(Methods of Environmental Research: a study guide for universities [stamp FUMO

"Earth Sciences"]/ KaverinaN.V., Prozhorina T.I., Ivanova E.Yu., Klevtsova M.A., Kurolap S.A., Klepikov O.V., Muravyov A.G., Nikolskaya A.N., Sinegubova V.V. Voronezh, Publ. house "Scientific book", 2019. 355 p.)

\author{
A. G. Kornilov $\bowtie$ \\ Belgorod State National Research University, Russian Federation \\ (308015, Belgorod, Pobedy st., 85)
}

For citation: Kornilov A.G. New Practice-Oriented Study Guide for Environmentalists. Vestnik Voronezskogo gosudarstvennogo universiteta. Geografia geoekologia, 2020, No. 3, pp. 98-100. (In Russ.) DOI: https://doi.org/10.17308/geo.2020.3/3030

Conflict of interests: The author declares no information of obvious and potential conflicts of interest related to the publication of this article. 


\section{A. G. Kornilov}

Корнилов Андрей Геннадьевич

доктор географических наук, профессор, заведующий кафедрой географии, геоэкологии и безопасности жизнедеятельности Института наук о Земле Белгородского государственного национального исследовательского университета, г. Белгород, Российская Федерация, ORCID: https://orcid.ogr/0000-0002-9189-8965, e-mail: kornilov@bsu.edu.ru
Andrey G. Kornilov

Dr. (Geogr.) Sci., Professor, the Head of the Department of Geography, Geoecology and Life Safety, Institute of Geosciences, Belgorod State National Research University, Belgorod, Russian Federation, ORCID: https://orcid.ogr/0000-0002-9189-8965, e-mail: kornilov@bsu.edu.ru 